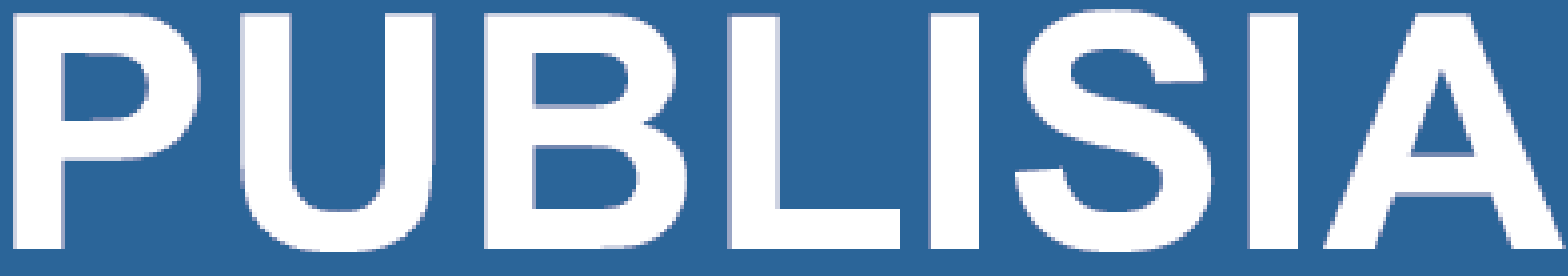

\title{
Jurnal Ilmu Administrasi Publik
}

Buruh anak: mamp ukah kebijakan negara melind ungi?

FajarAprani

Pembinaan Anak Jalanan Melalui Home Shelter "Griya Baca" Kota Malang Sebagai Upaya Menuju Kota Layak Anak

Erfinandus G. Sebawan

Calur Wahyudi

Sn Hartini Jatnikowali

Remunerasi dan Problem Reformasi Birokrasi Di Indonesia

Happy Susanio
Implamentasi Undang - Undang No mor 23 Tahun 2002 Tontang Porilindungan A nak Dalam Rangka Mowujdukan Kota Madang Sobagd Kota Layak Anak (Studl pada Dinas Soslal Pamerintah Kota Matangl

Dpo Pratoma

Tighonulin Dongl Ryanto

Penerapan New Public Management (NPM) DI Indonesia (Reformasi Birokrasi, Desentralisasi, Kerjasama Pemerintah dan Swasta Dalam Meningkatkan Pelayanan Publik)

AniAgus Puspawati

Studi Etnografi Perilaku Pengemis Masyarakat Desa Pragaan Daya Kabupaten Sumenep

Rina Hardyantina

Sukardi

Media Difusi Efektif untuk Sosialisasi Kebijakan Akselerasi Pengembangan PasarTradisional MenujuSemi Modern

Saldah

\section{PROGRAM STUDI ADMINISTRASI PUBLIK FAKULTAS ILMU SOSIAL DAN ILMU POLITIK UNIVERSITAS MERDEKA MALANG}




\title{
P U B L I S I A \\ JURNAL ILMU ADMINISTRASI PUBLIK \\ Diterbitkan Oleh \\ Program Studi Administrasi Publik \\ Fakultas IImu Sosial dan IImu Politik \\ Universitas Merdeka Malang
}

PUBLISIA (Jurnal IImu Administrasi Publik) merupakan terbitan berkala ilmiah yang diterbitkan Oleh Program Studi Administrasi Publik - FISIP Universitas Merdeka Malang. Memuat berbagai hasil kajian teoritik dan hasil penelitian di bidang Administrasi Publik dengan tujuan untuk membangun kolaborasi antar komunitas epistemik di bidang Administrasi Publik.

Awal berdirinya, ditahun 1997 jurnal ini bernama "Publisia: Jurnal Kebijakan Publik" terbit sebanyak 4 kali dalam setahun, kemudian ditahun 2004 mendapatkan ISSN (p) 1410-0983 dengan judul terbitan "Publisia: Jurnal Sosial dan Politik". Ditahun 2014, terbitan berkala ini berganti judul dengan "PUBLISIA (Jurnal IImu

Administrasi Publik) yang terbit secara cetak. Ditahun 2016 terbit dalam 2 versi (Cetak dan Online), perubahan sub judul pada terbitan berkala ini diajukan pembaruan sehingga ISSN (p): 2541-2515, di versi

online ISSN (e): 2541-2035. Setiap tahun terbit sebanyak 2 kali, di Bulan April dan Oktober.

Link Jurnal Online: http://jurnal.unmer.ac.id/index.php/jkpp

\author{
Ketua Penyunting \\ Chandra Dinata \\ Wakil Ketua Penyunting \\ Umi Chayatin \\ Penyunting Pelaksana \\ Budhy Priyanto \\ Catur Wahyudi \\ Praptining Sukowati \\ Dwi Suharnoko \\ Penyunting Ahli \\ Sukardi (Universitas Merdeka Malang) \\ Purwo Santoso (Universitas Gadjah Mada) \\ Bambang Supriono (FIA Universitas Brawijaya Malang) \\ Mas'ud Said (Universitas Muhammadiyah Malang) \\ Agus Solahuddin, MS. (Universitas Merdeka Malang) \\ Yopi Gani (Perguruan Tinggi IImu Kepolisian) \\ Kridawati Sadhana (Universitas Merdeka Malang) \\ Sujarwoto (FIA Universitas Brawijaya Malang) \\ Tri Yumarni (Universitas Jenderal Soedirman) \\ Mitra Bestari \\ Mudjianto (Universitas Negeri Malang)
}

Alamat Penyunting \& Tata Usaha: Gedung Fakultas Ilmu Sosial dan Politik (FISIP)

Unversitas Merdeka Malang, Jl. Terusan Raya Dieng 62-64 Malang 65145,

Telp. (0341) 580537, e-mail: publisia.jopad@unmer.ac.id 


\section{P U B L I S I A \\ JURNAL ILMU ADMINISTRASI PUBLIK \\ PROGRAM STUDI ADMINISTRASI PUBLIK - FAKULTAS ILMU SOSIAL DAN POLITIK \\ UNIVERSITAS MERDEKA MALANG}

\section{VOLUME 01, NOMOR 01, APRIL 2016}

\section{DAFTAR ISI}

Fajar Apriani Buruh anak: mampukah kebijakan negara melindungi?

Dipa Pratama Implementasi Undang - Undang Nomor 23

Tjahjanulin Domai Tahun 2002 Tentang Perlindungan Anak Dalam

Riyanto Rangka Mewujdukan Kota Malang Sebagai Kota Layak Anak (Studi pada Dinas Sosial

Pemerintah Kota Malang)

Erfinandus G. Setiawan

Catur Wahyudi

Sri Hartini Jatmikowati

Ani Agus Puspawati

Happy Susanto

Remunerasi dan Problem Reformasi Birokrasi

Di Indonesia

Rina Hardiyantina

Sukardi

Saudah
$54-69$

Pembinaan Anak Jalanan Melalui Home Shelter "Griya Baca" Kota Malang Sebagai Upaya Menuju Kota Layak Anak

Studi Etnografi Perilaku Pengemis Masyarakat Desa Pragaan Daya Kabupaten Sumenep $70-91$

Media Difusi Efektif untuk Sosialisasi Kebijakan Akselerasi Pengembangan Pasar Tradisional Menuju Semi Modern 


\title{
STUDI ETNOGRAFI PERILAKU PENGEMIS MASYARAKAT DESA PRAGAAN DAYA KABUPATEN SUMENEP
}

\author{
RINA HARDIYANTINA \\ SUKARDI \\ Program Studi Administrasi Publik - Fakultas Ilmu Sosial dan IImu Politik \\ Universitas Merdeka Malang
}

\begin{abstract}
Pragaan Daya village in Sumenep Regency is known as the village of beggars, for begging into people's daily work. Which became the main motive for people to do the work of begging is behavior "beg" hereditary so as to form a local cultural entities. In addition, the quality of human resources is still low which can result mindset people less creative and view life narrowly. Begging that can not be eliminated from Pragaan Daya vilagers be the reason why this work is still occupied them hereditary. Sumenep regency government has sought to address the begging behavior in their communities through the local legislation, the implementation of local government a persuasive approach to coaching, empowerment. Nonetheless, the fact that there are showing people in the hamlet village of Nong Pote vilages in Pragaan Daya still begging activity.
\end{abstract}

Key Word: Beggars, Motif, Gain, Behavioral social.

\section{Intisari}

Desa Pragaan Daya Kabupaten Sumenep terkenal dengan sebutan Desa pengemis, karena mengemis menjadi pekerjaan sehari-hari masyarakatnya. Yang menjadi motif utama bagi masyarakat untuk melakukan pekerjaan mengemis adalah perilaku "mengemis" yang turun temurun sehingga membentuk sebuah entitas budaya local. Selain itu, kualitas sumber daya manusia juga masih rendah yang dapat mengakibatkan pola pikir (mind set) masyarakatnya kurang kreatif dan memandang hidup secara sempit. Kebiasaan mengemis yang tidak dapat dihilangkan dari penduduk desa Pragaan Daya menjadi alasan mengapa pekerjaan ini masih ditekuni mereka hinngga turun temurun. Pemerintah Kabupaten Sumenep telah berupaya untuk mengatasi perilaku mengemis pada masyarakatnya melalui Peraturan Daerah, implementasinya pemerintah daerah melakukan pendekatan persuasif dengan pembinaan, pemberdayaan. Meskipun demikian, fakta yang ada menunjukkan masyarakat di Dusun Nong Pote Desa Pragaan Daya masih tetap melakukan aktifitas mengemis.

Key Word: Pengemis, Motif, Keuntungan, Perilaku Sosial.

\section{PENDAHULUAN}

Mengemis tidak sekedar dialami oleh masyarakat yang mempunyai masalah dalam bidang ekonomi, tetapi masalah budaya dan sistem sosial merupakan faktor dominan yang ikut andil dalam melahirkan tradisi mengemis. Mengemis lebih disebabkan oleh mentalitas individu yang tidak bisa lepas oleh sikap pragmatis untuk mencapai sesuatu. 70 | PUBLISIA (Jurnal IImu Administrasi Publik)
Mengemis atau perbuatan meminta-minta dititik beratkan pada faktor mental dan sikap malas.

Pragmatisme dan cara hidup yang serba pesimis serta instan dalam masyarakat merupakan cikal bakal yag ikut mendorong suburnya budaya mengemis. Tidak berlebihan, apalagi saya menilai bahwa bangsa ini dihuni oleh bangsa pengemis. Volume 1, Nomor 1, April 2016 
Terbukti, hampir diseluruh daerah dan kotakota besar yang ada di Indonesia seringkali kita menyaksikan komunitas gepeng, gelandangan atau yang lebih kita kenal dengan sebutan pengemis.

Hal ini menjadi potret nyata bangsa Indonesia, bahwa sebagian masyarakatnya hidup di bawah garis kemiskinan yang pada gilirannya mengemis dianggap jalan yang efektif untuk mencari kebutuhan dan dapat memenuhi hidupnya. Salahsatu efek meluasnya kemiskinan adalah semakin banyaknya masyarakat yang menggantungkan hidupnya pada orang lain dengan menjadi pengemis.

Mengemis adalah satu jenisaktivitas sosial yang dianggap masih tabudan rendah oleh sebagian masyarakat. Pekerjaan mengemis sebenarnya cenderung menghinakan dirinya sendiri (menorehkan luka di muka). Sementara jika bekerja, peluang laku (apalagi jika kerja di bidang yang dibutuhkan banyak orang) akan lebih besar. Selain itu, bekerja justru akan memuliakan diri. Dengan catatan, bahwa kerja dibidang yang halal. Dan yang perlu diperhatikan adalah mengemis hanya boleh dilakukan oleh orang yang tidak mampu bekerja lagi.

Amat paradoks manakala bangsa ini yang memliki kekayaan alam yang melimpah tetapi rakyatnya harus terlunta-lunta di bawah terik matahari dengan wajah kusut memohon belas kasihan orang hanya sekedar mendapat receh. Problem ekonomi atau kemiskinan bukan merupakan dalil baku yang menyebabkan masyarakat memiliki tradisi mengemis.

Berbagai faktor menjadi bagian penting yang menyebabkan masyarakat menjadi pengemis. Anggapan masyarakat terhadap pengemis yang dinilai miskin, kurang mampu akan terbantah manakala melihat realitas yang terjadi pada Masyarakat Desa Pragaan Daya di mana penduduknya mayoritas menjadi pengemis. Profesi pengemis ini menimbulkan pertanyaan-pertanyaan apa motivasi mereka menjadi pengemis sedangkan dalam konteks ekonomi mereka dikatakan mampu.

Di negara-negara berkembang,mengemis dianggap sebagai bagian dariprofesi. Di negara Afrika dan India, mengemis dianggap bagian dari pekerjaan, maka banyak muncul perkumpulan profesimengemis untuk mengatur kegiatan mereka. Masalah seperti ini di Indonesia bukan hal yang tabu lagi, keterdesakan ekonomi dan menaiknya jumlah angkatan kerja yang tidak tertampung menyebabkan banyak anak dan kaum dewasa terlibat dalam kegiatan ini meskipun dengan caradan teknik yang berbeda.

Desa Pragaan Daya terletak diwilayah Kabupaten Sumenep Madura, dimana mayoritas penduduknya berprofesi sebagai pengemis.Di Desa Pragaan Daya, 
tradisi mengemis semakin menjadi sudah terjadi sejak sekitar tahun 2000 dan menjadi kebiasaan turun temurun khususnya yang dilakukan oleh ibu-ibu paruh baya, anak-anak, dan lanjut usia.

Kebiasaan mengemis seperti ini akan mencapai puncaknya dengan jumlah pelakuyang besar dan meluas apabila bulan puasa sudah datang. Kebiasaan mengemis sudah menjadi sebuah profesi bagi mereka. Keadaan ini tentunya tidak lepas dariadanya latar belakang yang menjadi penyebabnya. Hal ini memunculkan suatu pemikiran dari pemerintah, khususnya pemerintah daerah kota Sumenep tentang bagaimana upaya yang dapat dilakukan untuk menanggulangi masalah pengemis tersebut.

Fenomena munculnya pengemis diindikasikan karena himpitan ekonomi yang disebabkan sempitnya lapangan kerja,sumber daya alam yang kurang menguntungkan dan lemahnya sumber daya manusia (SDM). Motivasi pengemis bisa didasarkan pada budaya mengemis yang turun temurun dan malasnya untuk bekerja. Praktek mengemis merupakan masalah sosial dan dianggap telah menyimpang dari nilai dannorma norma yang berlaku. Mereka adalah orang sehat dengan kondisi tubuh yang tidak kurang apapun (Bina Desa: 2007).

Sebagai kesimpulan dapatlah diterangkan bahwa kualitas manusia berada diantara naluri dan nurani. Dalam rentetan seperti itulah manusia berperilaku, baik perilaku yang positif maupun yang negatif. Fungsi intelegensi dapat menaikkan manusia ke tingkat yang lebih tinggi, namun intelegensi saja tidaklah cukup melainkan harus diikuti dengan nurani yang tajam dan bersih. Untuk itu, maka manusia memerlukan pembekalan yang kualitatif dan kuantitatif yang lebih baik dari pada hewan.

\section{PENGEMIS; ENTITAS SOSIAL YANG MENGGEJALA}

Realitas kehidupan sosial tidak luput dengan prilaku dan pola dari masyarakat itu sendiri. Salah satunya adalah pengemis atau sebagian orang menyebutnya dengan "Gepeng" Gelandangan dan Pengemis, potret sosial ini sering ditemukan dalam kehidupan.Adapun pengertian pengemis menurut Perpu No. 30 Tahun 1980 yang dikutip dalam buku Engkus Kuswarno (2009: 141) menyatakan : "Orang-orang yang mendapatkan penghasilan dengan memintaminta di muka umum dengan berbagai cara dan alasan untuk mengharapkan belas kasihan orang lain". (Kuswarno, 2009:141).

Berbeda dengan istilah pengemis yang diartikan oleh Dinas Sosial adalah PMKS (Penyandang masalah kesejahteraan sosial). "Pengemis adalah orang-orang yang mendapatkan penghasilan dengan mintaminta di tempat umum dengan berbagai cara dan alasan untuk mengharapkan belas kasihan orang lain". Dari pengertian diatas, 
selanjutnya bisa dilihat dari kelompokkelompok pengemis yang membedakan satu sama lain diantara pengemis yang ada.

Dari pengertian diatas, selanjutnya bisa dilihat dari kelompok-kelompok pengemis yang membedakan satu sama lain diantara pengemis yang ada.Dalam hal ini pengemis pun memiliki kelompok-kelompok yang membedakan motif-motif pengemis satu sama lain. Menurut Sudarianto dalam catatan onlinenya dimana pengemis dibagi menjadi 3 (tiga) kelompok pengemis, antara lain:

1. Mengemis karena tak mampu bekerja, pada kategori inidilakukan oleh orangorang yang mempunyai kelainan fisik pada anggota tubuhnya. Misalnya tak mampu bekerja karena tidak memiliki tangan, kaki, lumpuh, buta dan lain-lain.

2. Mengemis karena malas bekerja, pengemis karena malas bekerja inilah yang menyebabkan jumlah pegemis di Indonesia sangat banyak. Pengemis pada kategori ini, orangnya mempunyai anggota tubuh yang sangat lengkap namun dihinggapi penyakit malas. Pengemis semacam inilah yang harus diberantas oleh pemerintah.

3. Mengemis karena menginginkan jabatan, Pengemis semacam inilah yang merusak atau menghambat pembangunan di Indonesia. Mereka yang tergolong pada kelompok ini mengemis pada atasannya dengan berbagai cara untuk memperoleh job atau jabatan. Ada yang selalu bersilaturrahmi ke rumah atasannya, ada yang selalu memberikan hadiah kepada atasannya, ada juga yang gila hormat kepada atasannya, dan lain sebagainya.

Sedangkan Hanitijo Soemitrodalam Asmawi (2003:15), pengemis dibagi menjadi dua golongan, yaitu:Pertama, Pengemis Murni, ialah mereka yang mempunyai tempat tinggal tertentu maupun tidak, yang penghidupan seluruhnya atas dasar memintaminta pada waktu tertentu; dan kedua,Pengemis Tidak Murni, ialah mereka yang mempunyai tempat tinggal yang sebagian penghasilannya diperoleh dari meminta-minta pada waktu tertentu.

Dari penjelasan beberapa pakar tersebut, dapat dikategorikan bahwa "pengemis" itu merupakan sebuah entitas social baru dengan beragam motif. Pertama, pengemis berpengalaman: lahir karena tradisi, bagi pengemis yang lahir karena tradisi, tindakan mengemis adalah sebuah tindakan kebiasaan. Mereka sulit menghilangkan kebiasaan tersebut karena orientasinya lebih pada masa lalu (motif sebab). Kedua, pengemis kontemporer kontinyu tertutup: hidup tanpa alternative dengan tindakan mengemis menjadi satu-satunya pilihan yang harus diambil. Mereka secara kontinyu mengemis, tetapi mereka tidak mempunyai kemampuan untuk dapat hidup dengan bekerja yang akan menjamin hidupnya dan 
mendapatkan uang. Ketiga, pengemis kontemporer kontinyu terbuka: hidup dengan peluang, dengan memiliki alternatif pilihan, karena memiliki keterampilan lain yang dapat mereka kembangkan untuk menjamin hidupnya. Hanya saja keterampilan tersebut tidak dapat berkembang, karena tidak menggunakan peluang tersebut dengan sebaik-baiknya atau karena kekurangan potensi sumber daya untuk dapat mengembangkan peluang tersebut. Keempat, pengemis kontemporer temporer:merupakan kelompok pengemis yang tumbuh musiman. Pengemis kategori ini sifatnya hanya sementara dan bergantung pada kondisi musim tidak dapat diabaikan keberadaannya. Jumlah mereka biasanya meningkat jika menjelang hari raya. Daya dorong daerah asalnya karena musim kemarau atau gagal panen menjadi salah satu pemicu berkembangnya kelompok ini.Kelima,Pengemis berencana: merupakan kelompok pengemis berjuang dengan harapan.Pengemis ini hidup berjuang dengan harapan pada hakikatnya adalah pengemis yang sementara (kontemporer). Mereka mengemis sebagai sebuah batu loncatan untuk mendapatkan pekerjaan lain setelah waktu dan situasinya dipandang cukup.

Fenomena pengemis yang menjadi bagian dari fakta sosial kehidupan kita tidak lantas dari faktor-faktor yang melatar belakangiseseorang tersebut mengemis atau meminta-minta

dihadapan

calon

dermawannya. Banyak yang menyatakan faktor ekonomilah yang menjadi faktor utama mengemis, namun sebenarnya tidak hanya itu. Karena pengemis memiliki tujuannya masing-masing yang dipengaruhi oleh mental, akal pikiran dari pengemis terkait.

Secara lebih rinci, dalam prakteknya ada lima jenis pengemis yang disebabkan karena keterbatasan aset dan sumber ekonomi, rendahnya mutu mental seperti rasa malu dan spirit mandiri yang kurang. Dan faktor-faktor yang menjadi penyebabnya mengemis, diantaranya sebagai berikut :

1. Mengemis karena yang bersangkutan tidak berdaya sama sekali, mengemis dikarenakan tidak berdaya baik dari segi materi, karena cacat fisik, tidak berpendidikan, tidak punya rumah tetap atau gelandangan, dan orang lanjut usia miskin yang sudah tidak punya saudara sama sekali.

2. Mengemis menjadi bentuk keterpaksaan, dan tak ada pilihan lain. Mengemis seperti sudah menjadi kegiatan ekonomi menggiurkan, mulanya mengemis karena unsur kelangkaan aset ekonomi.Namun setelah beberapa tahun walau sudah memiliki aset produksi atau simpanan bahkan rumah dan tanah dari hasil mengemis tetapi mereka tetap saja mengemis. Jadi alasan mengemis karena tidak memiliki aset atau ketidakberdayaan 
ekonomi, untuk tipe pengemis ini tidak berlaku lagi. Sang pengemis sudah merasa keenakan. Tanpa rasa malu dan tanpa beban moril di depan masyarakat.

3. Mengemis musiman, misalnya menjelang dan saat bulan ramadhan, hari idul fitri, dan tahun baru. Biasanya mereka kembali ke tempat asal setelah mengumpulkan uang sejumlah tertentu. Namun tidak tertutup kemungkinan terjadinya perubahan status dari pengemis temporer menjadi pengemis permanen.

4. Mengemis karena miskin mental, mereka ini tidak tergolong miskin sepenuhnya. Kondisi fisik termasuk pakaiannya relatif prima. Namun ketika mengemis, posturnya berubah 180 derajat apakah dilihat dari kondisi luka artifisial atau baju yang kumel. Maksudnya agar membangun rasa belas kasihan orang lain. Pengemis seperti ini tergolong individu yang sangat malas bekerja. Dan potensial untuk menganggap mengemis sebagai bentuk kegiatan profesinya.

5. Mengemis yang terkoordinasi dalam suatu sindikat, sudah semacam organisasi tanpa bentuk. Dengan dikoordinasi seseorang yang dianggap bos penolong, setiap pengemis "anggota" setia menyetor sebagian dari hasil mengemisnya kepada sindikat. Bisa dilakukan harian bisa bulanan. Maka mengemis dianggap sudah menjadi profesi. Ada semacam pewilayahan operasi dengan anggotaanggota tersendiri.

Bertitik tolak kepada pengertian dan ciri-ciri serta tingkah pola, cara hidupnya, serta perbuatannya memang bukan mustahil kalau adanya gelandangan dan pengemis ini akan membawa dampak. Secara sepintas saja sudah dapat dilihat yaitu : menganggu keindahan lingkungan belum lagi ditinjau dari segi kesehatan.Secara keseluruhan dapat pula mempengaruhi lajunya pembangunan bangsa. Dalam karya ilmiah Asep Maryun (1987:50-51)menyatakan, dampak-dampak yang timbul karena gelandangan dan pengemis, ialah: 1]. Mempengaruhi lajunya pembangunan; 2]. Menganggu keindahan lingkungan hidup; 3]. Menimbulkan gambaran buruk terhadap bangsa; 4]. Gangguan keamanan dan ketertiban; 5]. Mempengaruhi kehidupan masyarakat sekitarnya; 6]. Mewarisi kehidupan bodoh; 7]. Menganggu kelancaran pendataan penduduk; 8]. Berkembang menjadi tuna susila; 9]. Kemungkinan pembawa sumber penyakit; dan 10]. Hilangnya percaya diri.

\section{PRAGMATISME HIDUP SEBAGAI ARUS UTAMA KEBIASAAN MENGEMIS \\ Munculnya Budaya Mengemis Di Desa Pragaan Daya}

Tidak ditemukan data secara pasti yang mencatat sejak kapan munculnya tradisi mengemis di Desa Pragaan Daya. Akan tetapi 
beberapa informan mengatakan bahwa tradisi mengemis itu telah adasejak zaman penjajahan Belanda, antara tahun 19301940an. Begitu kuatnya akar kebiasaan mengemis dalam sistem kekerabatan dan kehidupan pada masyarakat Pragaan Daya, sampai ketika setiap ada orang yang akan menjadi menantu ditanya dulu apakah bisa mengemis atau tidak. Bertahannya budaya mengemis di desa ini tersugesti oleh 'filsafat hidup' yang dipegang oleh leluhur bahwa kalau ingin kaya harus miskin dulu, di mana miskin dimaknai dengan susahnya untuk mempertahankan hidup, sehingga pemikiran itu mendorong orang untuk giat bekerja dan berperilaku hemat dengan apa yang mereka dapat.

Mayoritas responden dalam penelitian yang dilakukan, termasuk para pengemis sendiri tidak tahu persis sejak kapan budaya mengemis itu muncul karena yang mereka lakukan saat ini hanya menjalankan tradisi dari nenek moyang. Satu hal yang menarik adalah para pengemis menyadari bahwa fenomena ini akibat penjajahan Belanda yang hanya berfikir bagaimana mendapatkan keuntungan ekonomi yang besar tanpa memperdulikan nasib rakyat. Maka yang terjadi rakyatmenjadi miskin ekonomi dan psikis.Budaya mengemis dilakukan karena di benak mereka tidak adajalan lain untuk memenuhi kebutuhan hidup kecuali dengan mengemis.
Setidaknya ada empat faktor yang mempengaruhi diri mereka sehingga menjalani profesi mengemis yaitu kondisi alam yang gersang, lemahnya sektor ekonomi (akses dan permodalan), pendidikan dan stereotype. Keputusasaan ini muncul karena pekerjaan yang mereka lakukan tiap hari seperti mencari kayu bakar, mengumpulkan batu-batu kecil digunung yang kemudian dijual dirasa kurang mencukupi kebutuhan seharihari.Kondisi alam di desa ini termasuk daerah yang tandus dan tanah berbatuan, tidak seperti daerah lain yang dalam satu tahun bisa menanam padi, jagung, tembakau, kacang-kacangan dan lain sebagainya.

Kalau tohada yang menanam jagung dan kacang-kacangan hasilnya kurang maksimal baik dari segi kualitas dan kuantitas yang disebabkan faktor keringnya air yang hanya menunggu datangnya musim hujan serta minimnya pengetahuan tehnik pengolahan pertanian.Faktor alam mempunyai pengaruh dalam membentuk mental dansikap manusia. Kondisi alam yang baik menimbulkan gairah hidup secarabaik dan layak, demikian juga sebaliknya.

Meskipun di desa ini terdapat potensi ekonomi yang baik untuk dikembangkan berupa pohon siwalan, tetapi masyarakat tidak mengembangkan menjadi home industry dengan pengembangan teknologi tepat guna serta pengembangan sumber daya alam lainnya. Masyarakat Pragaan Daya "kalah" 
dengan situasi alam sehingga mereka mencari alternatif pekerjaan untuk menghidupi keluarga dengan mengharapkan uluran tangan dan belas kasihan orang lain. Bagi pengemis yang sudah berumur 50 tahun ke atas, orientasi hidupnya diarahkan untuk pemenuhan biaya hidup dasar, sedangkan bagi kaum muda, orientasinya tertuju ke barang-barang seperti sepeda motor dan alat rumah tangga lainnya.

Secara geografis, desa Pragaan terisolir dari sektor industri dan diperparah oleh minimnya fasilitas untuk menjalankan usaha dan ketidakmampuan mengakses ke lembaga-lembaga ekonomi. Sementara itu, tingkat pendidikan masyarakat Pragaan Daya sangat minim, mereka yang memiliki pendidikan setingkat SMA dan S1 berjumlah $15 \%$, selebihnya tidak sekolah atau tidak tamat SD. Pendidikan memiliki pengaruh terhadap pembentukan pola fikir, tingkah laku dan sikap. Paling tidak, melalui pendidikan akandiperoleh pengetahuan dan keterampilan yang dapat menumbuhkan kepribadian yang kreatif,mandiri dan bertanggung jawab.

Terobosan di bidang pendidikan sangat diperlukan dengan tujuan untuk menyadarkan mereka tentang makna hidup, membangun mental progresif dan berwawasan luas. Kalangan masyarakat Pragaan Daya memiliki anggapan bahwa tujuan hidup hanya sekedar untuk makan dan pemenuhan kepentingan jasmani. Kenyataan ini merupakan akibat dari taraf pendidikan yang rendah sehingga mereka tidak memiliki kreatifitas untuk mencari usaha yang prospektif, maka mengemis menjadi satu -satunya pilihan untuk dilakukan.Faktor lain yang dianggap memiliki pengaruh terhadap realitas ini adalah status sosial masyarakat Madura yang pada umumnya memiliki pekerjaan sebagai pekerja atau buruh. Dengan posisi sebagai buruh dan pekerja, berdampak terhadap pola fikir dan sikap masyarakat. Mereka tidak memiliki kesempatan untuk berpikir dan mengembangkan potensi diri.

\section{Ideologisasi Nilai Luhur dalam Keluarga}

Banyak ilmuwan sosial menyatakan bahwa keluarga merupakan lembaga yang paling penting dalam mensosialisasikan suatu nilai terhadap kepribadian seseorang. Demikian pula halnya dengan nilai-nilai tentang kepengemisan di Desa Pragaan Daya, Sumenep, Madura. Pertama, nilai tersebut disosialisasikan melalui kehidupan keluarga. Ada pendapat dari masyarakat di Desa Pragaan Daya yang meyatakan bahwa "pekerjaan mengemis bukanlah nista, karena ini juga jalan yang halal" (Petikan Wawancara, 21/11/16)

Pemahaman mengenai cara mencari nafkah dengan jalan mengemis pun sudah tertanam lama dari satu generasi ke generasi. Para sesepuh memberikan indoktrinasi bahwa pilihan pekerjaan untuk bertahan hidup yang bisa mereka lakukan adalah mengemis, maka 
wajar bila dalam satu keluarga tertanam mental mengemis. Sosialisasi mengenai hal ini terus berlangsung dan tak pernah ada yang mempersoalkan.

Dalam proses sosialisasi nilai ini banyak pula keluarga komunitas pengemis Pragaan Daya ini yang meniru orang-orang yang sukses setelah lama pergi dari kampung. Seperti diutarakan oleh tokoh masyarakat Desa Pragaan Daya dibawah ini:

"Rata-rata masyarakat sini suka heran, kok ada orang yang berangkat tanpa modal kemudian pulang kampung membawa uang atau barang. Saya kira wajar, siapapun akan dibuat iri, karena bagaimana bisa keluar kota satu bulan, kemudian begitu kembali ke kampung sudah membawa Televisi berwarna bahkan terkadang juga perabotan rumah tanggalainnya yang bagusbagus"

Sumber: Data lapangan, diolah.

Dari sikap tersebut, kemudian mereka tertarik untuk ikut meniru perilaku tersebut. Karena tidak memiliki keahlian yang bisa diandalkan, atau juga koneksi dengan orangorang di kota, maka mereka mencari jalan yang paling mudah, yakni menyulap diri menjadi pengemis. Mengemis sudah menjadi pekerjaan yang populer, hampir semua atau sebagian besar masyarakat Pragaan Daya pernah melakukannya. Salah satu fenomena lain yang menarik adalah realitas di kampung Pragaan Daya dengan penduduk $50 \mathrm{KK}$, di mana hampir semua penduduknya bermata pencaharian pedagang.

Tetapi di saat krisis ekonomi melanda ditandai dengan naiknya harga kebutuhan 78 | PUBLISIA (Jurnal IImu Administrasi Publik) pokok, banyak orang yang tidak bisa bertahan. Alhasil, mereka yang semulaberdagang ini pindah profesi sebagai pengemis dan pengalaman ini kemudian menjadi pekerjaan, karena penghasilannya lebih banyak dari berdagang. Dengan mengemis mereka justru mampu membayar hutang-hutangnya,bahkan uang itu masih tersisa.

Dari 50 Kepala Keluarga yang ada di kampung Pragaan Daya ini, sekarang tinggal 2 persen yang masih menekuni profesi sebagai pedagang, dan selebihnya (98 persen) beralih profesi sebagai pengemis. Profesi mengemis bagi masyarakat Pragaan Daya bukan menjadi pekerjaan sampingan, tetapi sudah menjadi pekerjaan pokok.Ketika membelanjakan hasil mengemis, selain untuk makan, dibelikan juga perhiasan emas. Kalau sudah terkumpul dan cukup untuk dibelikan sapi motor, maka emas itu dijual lagi untuk dibelikan sapi. Kemudian sapi itu dipeliharakan pada orang lain dengan sistem bagi hasil (paroan) atau langsung dijual untuk dibelikan tanah". Bahkan tidak sedikit masyarakat Pragaan Daya yang mengalokasikan uangnya untuk membiayai anak sekolah dan mengirim anak ke pondok pesantren. Sejak kecil anggota keluarga terlibat dalam mencari dan mengelola uang dengan cara mengemis, sehingga mengemis telah tertanam dalam diri setiap anggota keluarga, dan pekerjaan mengemis itu tidak 
saja halal tetapi juga mulia. Dengan cara tersebut mereka sudah turut memenuhi kebutuhan keluarga, termasuk dalam membangun rumah,menyekolahkan anak, mengantarkan kakak, adik atau bahkan saudara untuk menuntut ilmu ke pondok pesantren.

Jadi di dalam keluarga di desa Pragaan Daya sosialisasi nilai mengenai mengemis ini sudahberjalan dari satu generasi ke generasi berikutnya selama bertahun-tahun. Persoalan mendasar bagi masyarakat Pragaan Daya adalah bagaimana terus memperbaiki modus dan melakukan inovasi di dalam mengemis sehingga mampu menghasilkan uang sebanyak-banyaknya.

Dalam konteks pembaharuan model mengemis dikenal apa yang disebut mengemis dengan cara non-konvesional, yang dikenal sejak tahun 1980-an. Mengemis dengan cara non-konvensional dilakukan dengan cara menyodorkan surat dan proposal atas nama suatu yayasan atau lembaga pendidikan untuk diedarkan terutama di kotakota besar di Indonesia.Ternyata modus baru ini memang membawa hasil yang jauh lebih banyak dari pada mengemis secara konvensional.

Contoh modus baru ini adalah dengan mengedarkan surat dan proposal berlabel yayasan. Selama seminggu mereka bisa mendapatkan uang sebesar satu juta rupiah. Jumlah tersebut kemudian dibagi dua dengan pemilik yayasan dengan komposisi 30 persen pencari dana dan 70 persen untuk pemilik yayasan. Pendapatan kadangkala bisa mencapai Rp5 juta. Begitu mendapat uang dalam jumlah besar, mereka langsung membelanjakan untuk membeli sapi, televisi, sepeda motor dan sebagian disimpan secara pribadi. Indikator dari kesuksesan para pengemis non-konvesional ini tampak dari kemampuannya membangun rumah bagus.

Bila dibanding dengan teknik konvensional, modus baru ini lebih menguntungkan, karena pengemis konvensional hanya mampu mengumpulkan antara $\mathrm{Rp} 10$ ribu sampai $\mathrm{Rp} 20$ ribu perhari.Kendala teknis yang dihadapi oleh pengemis non-konvensioal adalah berkaitan dengan bagi hasil antara pemilik yayasan atau lembaga pendidikan dengan pencari dana yang dianggap tidak adil. Pemilik yayasan hanya mendapatkan antara 25 sampai 30 persen, sedangkan selebihnya bagi pencari dana, termasuk dana makan selama beroperasi,transport, living kost dan kebutuhan lainnya. Untuk mengatasi problem ini, dibuat kesepakatan bahwa pencari dana wajib membayar uang jasa ke pemilik yayasan berkisar antara Rp 300 ribu hingga Rp 400 ribu tiapbulan, selebihnya milik pencari dana.

\section{PERILAKU MENGEMIS, CORAK} KEHIDUPAN BANGSA YANG MEMUDAR 
Lingkungan masyarakat memiliki kontribusi dalam pembentukan kepribadian dan kebudayaan seseorang. Dalam konteks kemasyarakatan, proses sosialisasi nilai mengemis ini terjadi pada anggota masyarakat Desa Pragaan Daya karena mereka hidup di lingkungan komunitas pengemis. Meskipun lambat namun pasti, kebiasaan mengemis telah menjadi tradisi dan bagian dari kehidupan di Desa Pragaan Daya.

Salah satu bentuk sosialisasi nilai mengemis pada level kemasyarakatan adalah melalui tradisi hajatan (parlo), seperti acara perkawinan, khitanan anak/cucu. Berbagai bentuk hajatan ini telah menuntut mereka untuk mengumpulkan uang dalam rangka menyukseskan acara tersebut. Biaya acara perkawinan pada tahun 2015 sebesar kurang lebih $\mathrm{Rp} 25$ juta. Kalau ternyata uangnya kurang, mereka berani meminjam uang ke tetangga atau rentenir yang rata-rata berbunga 20 persen perbulan.

Untuk membayar hutang, mengemis menjadi solusi yang dipilih atau mereka menjual tanah dan pohon siwalan yang cukup banyak di kampung mereka. Kondisi tesebut diperparah oleh perasaan gengsi bila hanya memberikan kado sebesar 50 ribu pada sebuah resepsi pernikahan, khitanan dan acara besar lainnya. Dua faktor tersebut, "parlo" dan gengsi, telah menjadi dan dijadikan beban dalam kehidupan sosial masyarakat yang sekaligus berfungsi sebagai pemicu pengekalan budaya mengemis.

Sejak tahun 1980-an, "parlo" tidak hanya sebagai prosesi ritual perkawinan saja, namun juga dijadikan lahan untuk mendapatkan uang. Uang yang didapat dipakai untuk membayar utang, membuat rumah bahkan modal untuk ke Mekkah. "parlo" diselenggarakan dengan cara tuan rumah menunjuk seseorang sebagai ketua "parlo" yang bertugas menyampaikan undangan, biasanya berbentuk kertas atau berupa rokok 1 bungkus). Undangan tersebut disebarkan minimal satu minggu sebelum hari "H".

Pihak yang diundang sudah ditentukan terlebih dahulu, dengan nuansa pemaksaan, untuk membawa barang atau uang yang jumlahnya sudah ditentukan pula oleh ketua "parlo", seperti misalnya diharuskan membawa beras sebanyak 3 sampai 5 kuintal. Jika pada hari "H" pihak yang diundang tidak menyerahkan beras atau barang yang telah ditentukan, maka jumlah barang tersebut akan 'dikurs' dengan uang (rupiah).

Pihak yang diundang diharuskan memberikan sejumlah uang yang ditentukan oleh ketua "parlo".Jika pihak terundang tidak mampu memenuhi acara "parlo", maka peranan ketua "parlo" menjadi penting dan menentukan. Ketua "parlo" memberikan pinjaman kepada yang punya hajat dengan bunga 20 persen perbulan. Posisi ketua 
"parlo" lebih mirip dengan rentenir yang siap memfasilitasi kebutuhan yang punya hajat.

Keberadaan rentenir di Desa Pragaan Daya berkembang di hampir setiap dusun. Pada awalnya, kegiatan ini dilakukan oleh tokoh masyarakat lokal sebagai tempat meminjam uang bagi warga yang kesulitan hidup. Tradisi ini kemudian menjadi kebiasaan di tengah masyarakat, artinya siapapun yang pinjam uang meskipun ke keluarga sendiri, secara tak langsung sudah "menyetujui" untuk membayar bunga 20 persen.

Apabila pihak terhutang tidak mampu membayar hutang dan bunganya, maka pihak penghutang tidak segan-segan menyegel tanah ataupun barang berharga lainnya sebagai bentuk pelunasan hutang tersebut.Selain budaya rentenir, di desa Pragaan Daya juga berkembang kebiasaan arisan dengan nominal Rp 50 ribu perminggu, dan budaya memberi sajian berupa makanan kepada tamu yang datang di rumahorang yang baru pulang dari mengemis. Biasanya, tamu yang bersilaturrahim menanyakan untung tidaknya dalam mengemis. Kalau jawabnya untung, maka tamu itu pasti diberi makan nasi.

\section{MENGEMIS UNTUK KEPENTINGAN} EKONOMI, RAGAM DAN CORAK DALAM MENUAI SIMPATI

Praktek mengemis dilakukan pertama kali secara individual, baik dalam hal keberangkatan maupun penentuan daerah operasi. Keuntungan model individual ini adalah kebebasan menggunakan hasil yang diperoleh.Mereka menjalankan profesinya secara penuh waktu, berangkat pagi sekitar pukul enam dan pulang menjelang Maghrib. Perjalanan ketempat mengemis ditempuh dengan berjalan kaki bila jaraknya dekat. Namun bila jarak cukup jauh, mereka menginap di tempat-tempat umum seperti masjid dan balai desa.

Hasil mengemis dapat diklasifikasikan menjadi 2 (dua) kategori uang dan barang. Kalau uang, biasanya mereka tidak langsung membelanjakan, tetapi disimpan dahulu sampai cukup untuk membeli barang atau hewan piaraan seperti ayam, kambing dan kebutuhan rumah tangga lainnya. Jika hasilnya berupa barang seperti jagung, sebagian dimasak dan selebihnya disimpan untuk dijual. Hasil penjualan jagung dikumpulkan dan dijadikan satu dengan uang hasil mengemis.

\section{Praktek Mengemis Konvensional}

Pengemis konvensional atau bersifat individual basis operasinnya di daerah Kabupaten Sumenep dan Pamekasan, namun ada juga yang merantau ke luar Madura seperti Jember, Probolinggo, Pasuruan, Banyuwangi dan Jakarta dengan basis masyarakatnyaketurunan Madura.Ada beberapa alasan mengapa mereka memilih 
kota-kota tersebut. Pertama, komunikasi lebih mudah karena sama-sama bisa berbahasa Madura. Kedua, ada filosofi yang berkembang di kalangan orang Madura bahwa kalau mereka saling bertemu meskipun tidak saling kenal, mereka tetap disebut saudara. Ketiga, orang Madura diperantauan secara umum dianggap relatif sukses sehingga tidak enggan untuk mensedekahkan sebagian hartanya.

Meski demikian, sasaran mengemis tidak sebatas orang Madura, siapapun akan diminta, termasuk orang non muslim (Warga Keturunan).Pada perkembangan selanjutnya, ada 2 (dua) bentuk objek pengemisan yaitu uang dan barang. Di lihat dari sisi waktu, kegiatan bentuk pertama ini mereka lakukan setiap hari sepanjang tahun. Sedangkan kategori kedua biasanya dilakukan pada saat musim tertentu,seperti musim panen jagung. Pada musim panen, modus yang dilakukan adalah mereka berangkat bersama-sama (minimal dua orang) menuju satu desa tertentu lengkap dengan karung.

Mereka bermalam di rumah penduduk atau di balai desa atas ijin penghuni. Soal tempat tidak pernah mereka persoalkan, yang penting mendapatkan ijin untuk bermalam. Ketika akan meminta, mereka kadang-kadang ikut membantu memetik hasil panen meskipun hanya sebentar sambil menunggu makan siang. Kadangkala mereka juga langsung meminta-minta pada saat satu keluarga sedang memetik hasil panen atau langsung mendatangi rumah-rumah penduduk. Dalam musim panen tersebut, penghasilan mereka rata-rata sekitar 20 kilogram.

Hasil yang diperoleh kemudian pada malam harinya dikumpulkan ditempat penginapan untuk kemudian dibawa pulang atau langsung dijual. Bagi mereka yang kebutuhan hidup selama mengemis kurang,maka hasil mengemis langsung dijual, sedangkan bila cukup, maka barang tersebut dibawa pulang dan disimpan untuk makan sekeluarga, sebagian lagi dipergunakan untuk menanam jagung, bagi yang punya sawah. Sebagaimana profesi lain, dunia pengemis pun mengenal persaingan.

Persaingan terjadi ketika memperebutkan daerah operasi.Seringkali para pengemis membentuk kelompok yang ditentukan atasdasar kedekatan rumah, hubungan famili dan teman dekat. Di antarasesama anggota kelompok kemudian membuat kesepakatan tentangdaerah mana yang akan dijadikan wilayah operasi, pukul berapaberangkat dan bermalam di mana. Pembentukan kelompok tidak harus dibuat formal, sebab prosesnya pun tidak formal, tidak ada aturan formal yang terlalu mengikat. Oleh sebab itu, antar anggota kelompok bisa saling bertukar tempat operasi sesuai dengan kesepakatan. Dari beragam sumber mengatakan bahwa sejak mereka mengemis belum pernah terjadi perselisihan apalagi 
pertengkaran, kecuali persaingan untuk mendapathasil yang banyak.

\section{Home to Home}

Para pengemis menggunakan strategi ini untuk mendatangi rumah-rumah, kantorkantor, toko-toko, warung dan bengkel yang ada dipinggir jalan. Pengemis individu biasanya beroperasi sesuai dengan keinginannya, artinya sasaran operasi tiap harinya bisa tetap, sehingga bisa jadi satu rumah didatangi pengemis 2 - 3kali sehari dengan wajah yang berbeda. Berbeda dengan pengemis yang dikordinir oleh "juragan" yang biasanya beroperasi di kota besar seperti Surabaya.

Para pengemis telah diatur (rolling) oleh juragan. Dari pantauan peneliti, ternyata dari hari ke hari dalam satu minggu para pengemis orangnya sama, hanya berbeda pembagian lokasi (antar RT/RW, antar gang atau antara jalan sisi barat- timur/utaraselatan). Kalau hari Senin si Fulan beroperasi di gangl, maka hari Selasa beroperasi di Gang II, Rabu di Gang III dan seterusnya. Demikian juga yang lain, pada hari Senin di gang II, Selasa di gang III,Rabu di gang IV, demikian seterusnya.Strategi ini diasumsikan oleh para "juragan" dan pengemis bahwa orang yang diminta mengira mereka yang beroperasi di rumah-rumah orangnya berbeda, sehingga ketika didatangi oleh pengemis akan memberi kembali.
Bagi para pengemis yang beroperasi di wilayah Madura, mereka juga memiliki jadwal kapan beroperasi di daerah A dan B. Biasanya pengemis lebih ramai ketika di suatu daerah ada hari pasaran. Jadi sasaran operasi ada dua, rumah di pinggir jalan dan pasar. Ketika menjelang akhir bulan puasa di saat dilakukan pembagian zakat, jumlah pengemis meningkat. Datangnya bulan suci Ramadhan tampaknya menjadi moment tersendiri bagi pengemis. Hal ini dibuktikan dengan semakin bertambahnya para pemintaminta di wilayah Kabupaten Sumenep. Pengemis tradisional yang beroperasi di Sumenep dan Pamekasan biasanya pulang tiap hari.

\section{Gendong Bayi}

Strategi ini sudah sering kita lihat dan kita juga pernah mengalami dimintai uang dengan cara seperti ini. Strategi ini dipraktekkan oleh parapengemis dari Pragaan Daya, khususnya bagi mereka yang beroperasi dikota besar seperti Surabaya. Ketika berangkat ke Surabaya, mereka hanya membawa baju dan peralatan secukupnya, namun ketika akan beroperasi mereka diberi umpan bayi yang disediakan oleh "juragan". Tujuannya dengan menggendong bayi agar orang yang melihat para pengemis ada belas kasihan, rasa iba dan trenyuh hatinya sehingga memberi sedekah. 
Bayi disediakan oleh juragan dengan cara menyewa atau pinjam,yang jelas para pengemis tidak tahu dari mana juragan mendapatkan bayi tersebut. Para pengemis cukup memberi air putih dan nasi kepada bayi yang biayanya diambil dari hasil mengemis, selain mereka harus memberikan setoran kepada juragan.

Sumber: Data Lapangan, diolah.

Praktek seperti ini secara finansial sangat menguntungkan para juragan yang mengatur bisnis pengemis. Realitas ini sangat kuat terindikasi adanya suatu sindikat yang mengatur "penyewaan" bayi bagi para pengemis di kota besar, seperti Jakarta dan Surabaya. Sedikitnya 3.000 bayi diperalat pengemis untuk mencari uang di jalan raya, dengan jumlah pengemis 10.000 orang. Berdasarkan pengamatan ,pengemis yang menggendong bayi lebih mengundang iba warga dibanding terhadap mereka yang tidak membawanya. Warga selalu tampak tidak tega untuk tidak memberikan uang.

\section{Membawa Barang}

Strategi ini dilakukan dengan cara membawa dagangan; jagung, gula merah, tembakau ke Jawa (luar Madura) untuk dijual. Setelah barang-barang terjual, mereka kemudian memakai pakaian pengemis.Jadi, mereka mendapatkan dua keuntungan, yaitu menjual barang danminta uang. Praktek ini biasanya dilakukan secara bersama-sama ketika berangkat, menjual barang, dan pulang, meskipun daerah operasi penjualan dan praktek mengemisnya berbeda. Seperti informasi yang diutarakan oleh Pak Panji Tauifik dalam petikan dibawah ini:

Tikar mereka beli di Probolinggo, misalnya, untuk dijual ke Sumenep, dan setelah tikar tersebut terjual mereka berangkat lagi ke Probolinggo untuk beroperasi mengemis. Jadi ada nalar bisnis untuk mendapatkan hasil yang lebih banyak".

Sumber: Data Lapangan, diolah.

Waktu yang dihabiskan untuk melakukan strategi ini paling lama dua - tiga minggu. Sasaran operasi mereka adalah warga Madura yang hidup di Jawa, seperti Pasuruan,Jember, dan Probolinggo.Namun yang menarik adalah terdapat unsur kreatifitas para pengemis yaitu setelah mereka mendapat uang banyak, mereka pulang tidak membawa uang tapi membawa barang, seperti tikar.

\section{Menanti di Warung}

Modus ini dilakukan oleh pengemis dengan cara beroperasi di malam harimulai dari pukul 18.00 WIB - 23.00 WIB. Hal ini terlihat di sekitar jalan Seludang Sumenep. Mereka hanya duduk di pojok warung yang biasanya ramai pengunjung dan menadahkan tangan kepada setiap orang yang selesai makan. Para pengemis ini rata-rata tiap malam mendapatkan maksimal Rp. 10.000,-Kalau dijumlah dengan pendapatan pagi hari menjadi antara Rp. 20.000 - Rp. 25.000,- per hari. 
Praktek Pengemis non Konvensional

Seiring dengan perkembangan zaman, maka model mengemispun mengalami dinamika yang cukup menarik sejak tahun 1980-an. Kegiatan mengemis mulai terorganisir dan diorganisir secara lebih rapi. Bila padaawal mula munculnya pengemis cenderung tidak terorganisir (sendiri-sendiri) namun pada tahun 1980-an terdapat perkembangan yang signifikan. Perkembangan yang paling menonjol adalah kemampuan mereka untuk mempetakan daerah sasaran operasi di luar kabupaten Sumenep dan pengembangan model pengemisan dengan cara-cara nonkonvensional.

Selama ini pengemisan hanya dilakukan secara konvensional,yakni mengemis dengan cara memelas, mengulurkan tangan dengan mengenakan pakaian compang camping seperti gelandangan. Sedangkan pengemisan secara non-konvensional adalah mengemis dengan penampilan lebih rapi (mengenakan celana atau sarung lengkap dengankopiah), membawa surat "resmi" dari lembaga/yayasan dan surat jalandari pemerintah. Bagi pengemis sistem konvensional biasanya dilakukan secara berkelompok dan terbentuk secara alami, tidak ada seorang organisator yang khusus menangani kelompok. Pada prinsipnya masing-masing individu bertanggung jawab atas keselamatan dirinya sendiri, danjuga masing-masing memiliki hak penuh untuk membelanjakan hasil mengemis.

Meski demikian hubungan antar individu, terjaga denganbaik, minimal sesama anggota saling mengetahui situasi dan kondisi.Sedangkan bagi pengemis yang dilakukan secara kolektif (nonkonvensiona)segala sesuatunya telah disiapkan secara matang, seperti surat jalan, proposal dan alat kelengkapan lainnya. Sasaran operasinya adalah kota-kota besar seperti Jakarta, Semarang, Batam, Bandung dan sebagainya.

Awal mula munculnya pengemis dengan cara non-konvensional adalah karena mereka meniru suksesnya kegiatan pengumpulan dana untuk pembangunan masjid atau yayasan. Salah satu contoh lembaga yang sukses dibangun dengan cara seperti ini adalah Lembaga Pendidikan Yayasan Hidayatut Thalibin yang diasuh oleh $\mathrm{KH}$. Abd. Mannan. "Yayasan ini dibangun sebagaian besar dananya dikumpulkan dengan cara surat menyurat atau membentuk panitia pencari amal secara door to door dengan membawa proposal resmi. Alhasil, kegiatan pencarian amal ini punsukses.

Dalam pelaksanaan pencarian amal ini, pihak yayasan memberikan stimulan berupa prosentase kepada pencari sebesar 20 persen dari jumlah total pendapatan. Pemberian prosentase kepada pencari dana sebagai rangsangan dan pengganti kerja yang dihitung 
perhari. Namun pada perkembangan selanjutnya, praktek pencarian dana seperti ini ditiru oleh masyarakat pengemis, satu cara yang cenderung manipulatif.

Sejak itulah muncul banyak yayasan dan lembaga pendidikan yang minta sumbangan untuk pembangunan masjid, pengembangan pendidikan dan kegiatansosial lainnya, yang tersebar di kota-kota besar di Indonesia.Praktik seperti ini terorganisir secara rapi, mulai tingkat desa sampai kota Kabupaten. Di tingkat desa, aktor yang mengorganisir biasanya orang yang memproses surat-surat kelengkapan administrasi pencarian dana, mulai dari pengurusan akte notaris sampai surat rekomendasi dari muspika.

Sedangkan di kota besar, orang yang mengorganisir adalah orang (Madura) yang sudah lama menggeluti profesi mengemis dan mengetahui peta daerah mana yang perlu dijadikan obyek sasaran. Proses terbentuknya pengelompokan pengemis di kota besar biasanya terjadi karena mereka sebelumnya sudah ada hubungan, baik melalui para sesepuh, senior atau keluarga yang pernah merantau di kota tersebut.

Pada umumnya, mereka tidur dan makan di rumah temannya yang ada di kota dengan sistem membayar bulanan. Karena daerah operasi yang cukup jauh, biasanya para pengemis ini pulang minimal sebulan sekali, bahkan ada yang setengah tahun.
Tetapi pada saat menjelang bulan Ramadhan, semua pengemis ini pulang ke kampung halaman. Mereka yang tidak pulang, hanya menitipkan uang kepada teman seprofesi yang pulang kampung.

Pada umumnya para pengemisini pulang membawa uang dan ada pula yang membawa barang-barang kebutuhan keluarga, seperti barang-barang elektronik dan perabot rumahtangga lainnya.Pengemis yang terhimpun dalam kelompok, biasanya mereka berangkat dari rumah secara bersama-sama, meski pulangnya seringkali tidak bersama-sama. Soal teknis kepulangan ini cukup bervariasi, ada sebagian anggota kelompok pulang setiap minggu, ada yang pulang setiap dua minggu, setiap bulan dan sebagainya.

Sebagian besar mereka tergantung pada hasil yang dicapai. Bila dalam satu minggu atau sepuluh hari sudah mencapai target minimal, mereka bisa langsung pulang. Sebaliknya, bila tidak mencapai target minimal mereka menunda kepulangan. Meskipun demikian, terdapat sejumlah pengemis yang telah mencapai target tetapi tidak pulang dan menitipkan uangnya kepada temannya yang pulang.

Setidaknya ada dua strategi yang dijalankan oleh pengemis nonkonvensional; pertama, dengan cara mengirim proposal ke berbagai pihak,seperti pejabat pemerintah, pengusaha/konglomerat, tokoh politik, 
artisdan kenalan yang dianggap kaya, yang berada di luar pulau Madura. Kedua, dengan cara datang langsung ke kota-kota besar tersebut, baik secara individu maupun berkelompok. Ketiga strategi ini secara administratif sudah lengkap, seperti proposal sebagaimana yang kita maklumi, akte notaris dan surat keterangan dari desa.

Strategi profesional dengan proposal atas nama yayasan mampu mendatangkan uang banyak. Para pengemis hanya kirim via pos atau berangkat ke kota-kota besar. Setelah mendapatkan uang banyak, merekapulang kampung dan membagi hasil sesuai kesepakatan dengan pemilikyayasan. Sistem bagi hasil inilah yang menjadikan mereka bergairahuntuk mencari dana dengan cara. Pelaksanaan strategi tersebut melalui jaringan. Sebelum pergi mereka sudah mengetahui "bos"nya di Jakarta, demikian juga di kota besar lainnya. Ini terjadi karena watak orang Madura yang berpikir bahwa di mana ada orang Madura itulah saudara, apalagi dari daerah yang sama dan memang ada ikatan keluarga.

Persiapan administrasi dilakukan oleh pengemis yang profesional ini lengkap dengan akte notaris, dan disebar luaskan oleh panitia dengan melibatkan banyak pihak. Sedangkan pemilik yayasan santai di rumah, menunggu hasil pembagian/prosentase dari para pencari dana. Ketika sistem tersebut dibandingkan dengan usaha sebuah yayasan yang betul- betul akan mengembangan lembaga pendidikan, maka prosentase 30\%: $70 \%$ adalah menjadi tidak masuk akal. Sebab, bagi mereka yang serius untuk lembaga pendidikan tidak demikian caranya, tapi mereka mengumpulkan parawali murid dan para donatur yang telah siap membantu.

Berdasarkan modus operasi disistem mengemis yang nonkonvensional, secara tak langsung ada kerja sama dengan aparat; mulaidari kades, camat, kepolisian (muspika). Kerja sama terselubung inimenguntungkan semua pihak, aparat dan pengemis, di mana ketikaproses pengurusan surat rekomendasi dan surat ijin, para peminta rekomendasi itu memberi sesuatu (uang). Disinilah perlunya penertiban yayasan, dan para notaris hendaknya lebih berhati-hati dalam memberikan akte yayasan khususnya di Pragaan Daya, dan menindak tegas para pencari amal yang memalsukan akte notaris itu.

Apalagi dengan Undang-undang yayasan yang baru, ini bisa dijadikan alat untuk mengefektifkan dan menertibkan yayasan-yayasan di Pragaan Daya, sekaligus pembinaan mental agar berfikir kreatif dan modern. Kendala lain yang muncul adalah terjadinya kerjasama antara oknum aparat dengan pengemis. Oknum petugas mengerti kapan para pencari amal (yayasan) itu datang, di mana mereka juga minta bagi hasil. Oleh sebab itu, sampai saat ini belum ada tindakan 
tegas terhadap praktik pencarian dana dengan mengggunakan yayasan fiktif ini.

Kecenderungan terbaru bagi pengemis profesional adalah mereka menggunakan HP (hand phone) dalam melakukan komunikasi, seperti yang beroperasi di Surabaya. Ratarata mereka mempunyai HP sebagai media komunikasi sesama pengemis profesional. Mereka menggunakan HP karena daerah operasi tidak tetap, sehingga perlu komunikasi yang on line di mana dan kapan mereka beroperasi. Setidaknya dengan HP itu mereka saling mengetahui tempat menginap dimalam hari, berapa pendapatan perhari/minggu/bulan, dan rencanahari berikutnya akan beroperasi di daerah mana serta kapan pulang.

\section{JARINGAN PENGEMIS DAN KEHIDUPAN SOSIALNYA}

Jaringan pengemis profesional dari Pragaan Daya sudah menyebar dikota kota kota seperti Surabaya, Cirebon, Batam, Jember dan Jakarta. Jaringan tersebut dirintis oleh orang atau kelompok yang hidup dikota dan bertindak sebagai "koordinator". Berdasarkan pada pemikiran bahwa orang madura adalah satu keluarga dan berada dalam lingkungan budaya yang sama, proses sosialisasi akan mengalir dengan sendirinya, apalagi bila diceritakan hasil-hasil materi dari hasil mengemis. Jaringan ini terbentuk karena dukungan dari satu keluarga, satu etnik dan satu lingkungan masyarakat.

Migrasi biasanya terjadi pada wilayah yang bisa menjanjikan peluang ekonomi yang lebih baik dan menjanjikan, akan tetapi dalam konteks pengemis Madura, migrasi juga dilakukan ke daerah-daerah dimana mereka sudah memiliki jaringan berdasarkan relasi keluarga dan teman. Orang Sumenep biasanya melakukan migrasi ke Situbondo dan Bondowoso, karena di kedua daerah tersebut hidup komunitas etnis Madura di Jawa.

Di sisi lain, orang Pamekasan dan Sampang melakukan migrasi ke Pasuruan, dan orang Bangkalan pergi ke kota Surabaya dan Gresik.Proses terbentuknya jaringan ada yang sudah mapan,tetapi ada pula dalam proses mencari, karena sebagian dari pengemis berangkat sendiri-sendiri dengan modal pas-pasan, sehingga mereka membutuhkan waktu untuk membuat jaringan.

\section{Kehidupan Sosial Pengemis}

Terjadinya

kemiskinan

pada masyarakat yang pada gilirannya mengakibatkan mereka menjadi pengemis bukan disebabkan oleh faktor struktural semata seperti akibat penjajahan Belanda atau Jepang, tetapilebih banyak disebabkan oleh faktor kultural. Sebab, bila disebabkan faktor struktural, tentunya banyak daerah lain yang pernah dijajah juga mengalami atau 
menjadi daerah miskin. Kemiskinan yang menghinggap pada masyarakat Pragaan Daya bukanlah kemiskinan secara material,tetapi merupakan miskin pengetahuan yang mengakibatkan mentalmereka kurang kreatif.

Dalam tatanan konsep, masyarakat Pragaan Daya sudah terlanjur ter stereotype sebagai desa yang terbelakang, padahal potensi alam dansumber daya manusianya bisa dikembangkan ke arah yang lebih baik. Indikator ekonomi yang menarik adalah terdapat potensi lokal yang cukup menjanjikan, yaitu omzet rata-rata sebuah warung bisa mencapai Rp. 3.000.000,- (tiga juta rupiah) per hari. Artinya terjadi proses komulasi uang cash yang besar. Eksistensi budaya mengemis telah terbangun sejak nenek moyang dan selanjutnya dilestarikan oleh anak cucu dan akhirnya menjadi pekerjaan turun temurun.

Persoalannya sebenarnya terletak padamentalitas dan etos kerja, sebab daerahdaerah lain yang kehidupannya lebih parah dari Desa Pragaan Daya tidak melakukan praktek mengemis. Mereka mau berusaha jadi sopir, kuli atau pekerjaan lain yang baik menurut etika. Oleh sebab itu, faktor kultural memiliki sumbangan dalam mempengaruhi pola pikir masyarakat selain faktor internal masyarakat, pengaruh media sebagai akibat globalisasi juga ikut berperan dalam melestarikan budaya mengemis pada masyarakat Pragaan Daya.

Budaya untuk menjadi kaya secara instan,tanpa diikuti kerja keras dan modal yang cukup membuat merekamencari jalan pintas untuk meraih dan memenuhi kehidupan hidup. Ketika melihat tetangganya membeli TV, mereka ingin memililiki TV juga, padahal mereka tidak punya uang. Jalan pintas yang ditempuh adalah membawa kertas yayasan, pergi ke daerah-daerah lain dengan alasan minta amal untuk masjid, pesantren dan sebagainya.

\section{KESIMPULAN}

Dari kajian ini dapat disimpulkan bahwa awal mula munculnya praktik mengemis di Pragaan Daya dimulai sejak pra kemerdekaan (1930- 1940an) dan berlangsung sampai sekarang. Bertahannya budaya mengemis disebabkan oleh lamanya praktek ini yang diwariskan secara turun temurun, disosialisasikan melalui kehidupan keluarga dan kehidupan masyarakat.

Dalam beberapa hal, kajian tentang kehidupan masyarakat pengemis di Desa Pragaan daya, Sumenep, Madura ini memperkokoh teori dan anggapan orang bahwa kemiskinanlah yang menyebabkan orang menjadi pengemis, dengan asumsi kesulitan ekonomi menjadi faktor tunggal di balik profesi kepengemisan ini. Dalam konteks ini, eksistensi pengemis dapat dipandang 
sebagai satu kategori dengan fenomena kaum miskin lainnya seperti gelandangan yang banyak hidup di kota-kota besar.

Namun jika kemiskinan didefinisikan sebagai suatu standar tingkat hidup yang rendah, yaitu adanya suatu tingkat kekurangan materi pada sejumlah atau segolongan orang dibandingkan dengan standar kehidupan yang umum berlaku dalam masyarakat yang bersangkutan, penelitian ini membuktikan bahwa tidak seluruh konsep dananggapan tersebut benar. Dalam kenyataannya, secara meyakinkan,masyarakat Pragaan Daya tidak bisa digolongkan kaum miskin, yang kekurangan materi, karena mereka berkecukupan jika diukur dalam standar kehidupan masyarakat pada umumnya memiliki rumah permanen, perabotan elektronik, sepeda motor dan sapi lebih dari satu ekor.Bila digolongkan sebagai kelompok kaum miskin, kemiskinan yang terjadi di kalangan komunitas masyarakat Desa Pragaan Daya Kabupaten Sumenep - Madura lebih dekat dengan kemiskinan dalam konstruksi Oscar Lewis.Lewis (1988:20) melihat masalah kemiskinan sebagai masalah ekonomi,yaitu tidak dikuasainya sumbersumber produksi dan distribusi bendabendadan jasa ekonomi oleh orang miskin; tidak juga melihatnya secaramakro, yaitu dalam kerangka teori ketergantungan antarnegara atau antar kesatuan produksi dan masyarakat dan tidak juga melihatnya sebagai pertentangan kelas sebagaimana yang dikembangkan oleh ilmuwan sosial Marxis.Oleh sebab itu bila lembaga pendidikan dan lembaga sosial berkembang dengan baik, pada gilirannya akan mampu mempengaruhi pola berfikir,sikap dan tingkah laku masyarakat, meskipun oleh banyak pihak dinilai lamban untuk merubah budaya itu.

Demikian sebaliknya, dengan pendidikan yang rendah akan mengakibatkan pola fikir yang kurangkreatif, memandang hidup secara sempit dan cenderung fatalistis.Oleh sebab itu, fenomena budaya mengemis di Pragaan Daya,secara umum diakibatkan oleh kemiskinan dirinya secara kejiwaan dan ekonomi (internal) dan dari luar (eksternal).

Bertahannya budaya mengemis secara turun temurun tidak lepas dari peran keluarga dalam mensosialisasi nilai-nilai pengemisan. Dalam kontek ini, terdapat dua pola sosialisasi di dalam keluarga dan sosialisasidi luar keluarga. Untuk yang pertama, sosialisasi dan terinternalisasi bermula ketika nenek moyang/orang tua mendoktrin, memberikan contoh dan mengajak anak cucu untuk mengemis.

Terkesan, mereka menikmati dengan profesinya dan merasa tidak ada beban dengan pekerjaan itu. Mengapa, sebab bagi mereka minta sumbangan seikhlasnya tidak dilarang oleh agama justru yang dilarang 
adalah mencuri. Pada sisi lain, aparat pemerintah setempat juga memberikan andil dalam membentuk budaya mengemis, yakni dengan begitu mudahnya mereka memberikan legalitas atau rekomendasi pencarian dana di tingkat pemerintahan desa dan jajaran 'muspika', tanpa ada pengecekan secara seksama.

Demikian juga, aspek pengawasan atau kontrol pemerintah masih lemah.Setelah menganalisa kompleksitas budaya mengemis di atas, makaperlu dilakukan terobosanterobosan untuk merubah atau setidaknya meminimalisir penyakit sosial itu. Fenomena sosial ini bukanlah semata-matamenjadi tanggung jawab pemerintah, namun diperlukan keterlibatan semua pihak, terutama tokoh-tokoh agama yang dilakukan secara sinergis. Dalam penelitian ini, setidaknya ada dua langkah strategis sebagai upaya meminimalisir budaya mengemis, yaitu pendekatan kultural dan struktural.

\section{DAFTAR PUSTAKA}

Asmawi, 2003, Karakteristik Pengemis Dan Golongan Pengemis, Gramedia Pustaka Utama, Jakarta.

Kuswarno, 2009, Pengemis dan Penanggulangannya, Yayasan Obor Indonesia, Surabaya.

Lewis, Oscar, 1959, Five Families: Mexican Case Studies In The Culture Of Poverty.

Maryun, Asep, 1987, Pengemis Serta Dampak Dampak yang Ditimbulkannya, Alfabeta, Bandung. 


\title{
PETUNJUK BAGI PENULIS TERBITAN BERKALA ILMIAH \\ P U B L I S I A \\ Jurnal IImu Administrasi Publik
}

\begin{abstract}
Naskah diketik spasi ganda pada kertas kuarto sepanjang maksimum 20 halaman dan diserahkan dalam bentuk cetak (print out) computer sebanyak 2 eksemplar beserta soft file didalam disk berbentuk document (Microsoft Word) atau dikirim melalui alamat email: publisia.jopad@unmer.ac.id
\end{abstract}

Artikel yang dimuat meliputi kajian dan aplikasi teori, hasil penelitian, gagasan konseptual, tinjauan pustaka, resensi buku baru, bibliografi, dan tulisan praktis berkaitan dengan ilmu sosial, terutama dalam lingkup kajian ilmu administrasi Negara.

Artikel ditulis dalam bahasa Indonesia atau Bahasa Inggris dengan format esai, disertai judul subbab (heading) masing-masing bagian, kecuali bagian pendahuluan yang disajikan tanpa judul subbab. Peringkat judul subbab dinyatakan dengan jenis huruf yang berbeda (semua judul subbab dicetak tebal atau miring), dan tidak menggunakan angka nomor subbab:

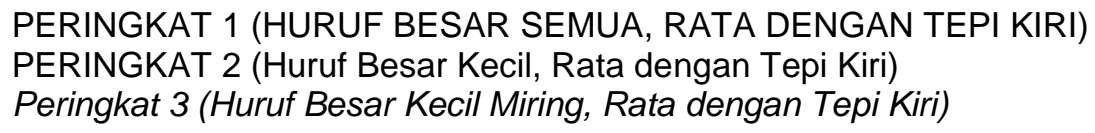

Sistematika artikel setara hasil penelitian: judul (diusahakan cukup impformatif dan tidak terlalu panjang. Judul yang terlalu panjang harus dipecah menjadi judul utama dan anak judul); nama penulis (tanpa gelar akademik); abstrak/intisari (maksimum 250 kata dengan disertai 3-5 istilah kunci (key word); pendahuluan (tanpa subjudul) yang berisi latar belakang dan tujuan atau ruang lingkup tulisan; bahasan utama (dibagi kedalam subjudul-subjudul); daftar rujukan (berisi pustaka yang dirujuk).

Sistematika artikel hasil penelitian: judul (diusahakan cukup impformatif dan tidak terlalu panjang. Judul yang terlalu panjang harus dipecah menjadi judul utama dan anak judul); nama penulis (tanpa gelar akademik); abstrak/intisari (maksimum 250 kata dengan disertai 3-5 istilah kunci (key word); pendahuluan (tanpa subjudul) yang berisi latar belakang, sedikit tinjauan pustaka, dan tujuan penelitian; metode; hasil; pembahasan; simpulan dan saran; daftar rujukan (berisi pustaka yang dirujuk).

Sistematika penulisan rujukan/daftar pustaka: rujukan/daftar pustaka ditulis dalam abjad secara alfabetis dan kronologis dengan ketentuan sebagai berikut:

a. Untuk buku: nama pengarang, tahun terbit, judul, edisi, penerbit, tempat terbit.

Contoh: Hicman, G.R. dan Lee, D,S., 2001, Managing humanresources in the public sector: a shared responsibility, Harcourt College Publisher, Fort Worth.

b. Untuk karangan dalam buku: nama pengarang, tahun, judul karangan, nama editor: judul buku, nama penerbit, tempat terbit, halaman permulaan dan akhir karangan.

Contoh: Mohanty, P.K., 1999, "Municipal decentralization and governance: autonomy, accountability and participation", dalam S.N. Jan and P.C. Mathur (eds): Decentralization and politics, Sage Publication, New Delhi, pp. 212-236

c. Untuk karangan dalam jurnal/majalah: nama pengarang, tahun, judul karangan, nama jurnal/majalah, volume/jilid, (nomor), halaman permulaan dan halaman akhir karangan.

Contoh: Sadhana, Kridawati, 2005, "Implementasi kebijakan dinas kesehatan dalam memberikan pelayanan pada masyarakat miskin", PUBLISIA, 9 (3): 156-171.

d. Untuk karangan dalam pertemuan: nama pengarang, tahun, judul karangan, nama pertemuan, waktu, tempat pertemuan.

Contoh: Utomo, Warsito, 2000, "Otonomi dan pengembangan lembaga di daerah", makalah disampaikan dalam Seminar Nasional Profesional Birokrasi dan Peningkatan Kinerja pelayanan Publik, 29 April 2000, Jurusan Administrasi Negara, FISIPOL UGM, Yogyakarta.

\section{Ketentuan lain:}

- Pemeriksaan dan penyuntingan cetak-coba dilakukan oleh penyunting dan/atau dengan melibatkan penulis. Artikel yang sudah dimuat dalam bentuk cetak-coba tidak dapat ditarik kembali oleh penulis.

- Penulis yang artikelnya dimuat wajib memberi kontribusi biaya cetak sebesar Rp. 250.000,- (Dua Ratus Lima Puluh Ribu Rupiah)*. 


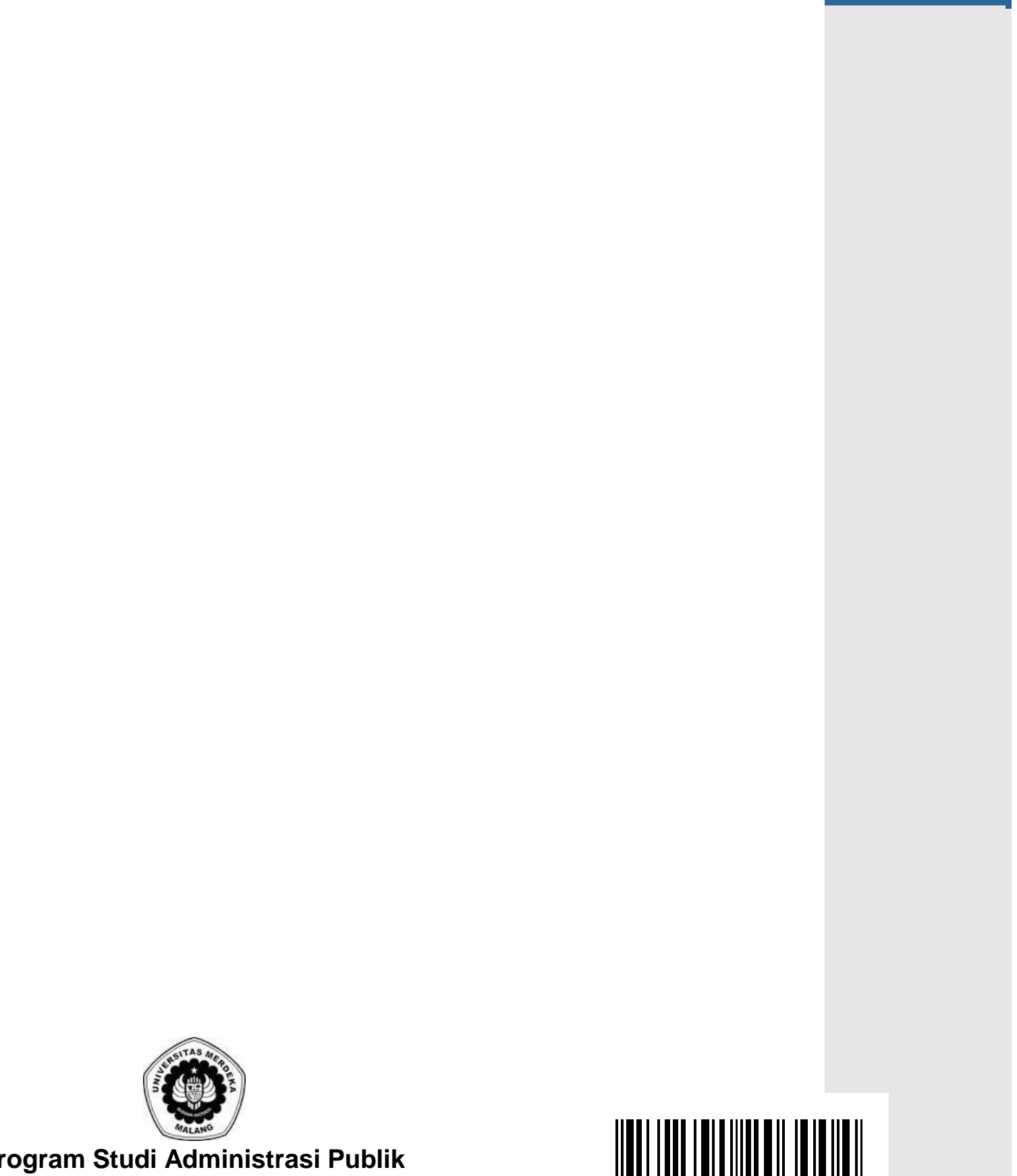

Program Studi Administrasi Publik FAKULTAS ILMU SOSIAL DAN ILMU POLITIK UNIVERSITAS MERDEKA MALANG

Jl. Terusan Raya Dieng no. 62-64 Kota Malang 65146

Telp. 0341-568395 psw. 873, Fax. 0341-580537 